\title{
TEACHERS' CITIZENS COMPETENCY: THE FRAMEWOK OF THE ISSUE (CHINESE EXPERIENCE)
}

Xie Fei ${ }^{1}$

Kalashnyk Lyubov ${ }^{2}$

DOI: https://doi.org/10.30525/978-9934-571-89-3_23

Modern education is experiencing essential changes that are manifested in organizational, managerial, legal, economic modernization, defining new educational goals that are to be adequate to the changes taking place in modern society. The importance of the educational process potential, the role of civic education, the development of democratic principles in the life of the school and the organization of social practice of students is growing. The social order requires the education system to carry out the preparation of an active, competitive person, competent in solving vital and professional problems, ready for carrying civic responsibilities, responsible for his own well-being and the welfare of the country. Traditionally the leading role in this process is given to a teacher who has to involve the younger generation in the core of the civic values of society and mankind.

The civic competence of a teacher is a set of readiness and abilities to implement in the educational process the principles of state policy in the field of education actively

\footnotetext{
${ }^{1}$ H.S. Skovoroda Kharkiv National Pedagogical University, Ukraine

${ }^{2}$ H.S. Skovoroda Kharkiv National Pedagogical University, Ukraine
} 
and responsibly, to be guided by normative and legal acts, to observe the rights and obligations of a democratic society member, to educate the younger generation in the spirit of humanism, freedom and love to the homeland. Today the civic competence of a teacher is attributed to the general, or basic competencies of the individual.

In the structure of a teacher's civic competence the following components are traditionally distinguished:

- cognitive (a system of gained civilian knowledge and concepts);

- axiological (oriented on personal attitudes of a teacher to society, himself/herself, includes motives, goals, needs, value systems, interest in social activities);

- behavioral (real behavior schemes, compliance with moral norms, performance of professional duties in accordance with their civil status);

- personal (self-esteem, creativity, reflection, tolerance, desire for cooperation, ability to choose and operate with information, expressed personal activity, positive attitude to fulfill civic duty with students, etc.) [2, p. 263].

Usually the spheres of teachers' civic competence manifestation are seen as following:

- competence in educational and cognitive activities (independent research and obtaining information from different sources, ability to analyze it and critically understand);

- competence in the field of socio-political and legal activities (realization of rights and obligations of a citizen, fulfillment of a citizen functions in co-operation with other people and authorities);

- moral and ethical competence (personal perfection of a teacher as a set of moral and ethical knowledge and skills to determine and evaluate his/her behavior, based on moral norms and ethical concepts that are correlated with humanistic and democratic values of modern society;

- competence in the socio-economic field (compatibility, suitability of personal qualities for the future profession, orientation to the labor market, knowledge of norms of professional and collective ethics) [1, p. 9].

The education of a worthy citizen of the country throughout the history pedagogical theory and practice has been and remains the main task of the education and training system in China and the People's Republic of China. However, the main efforts of the state in this process are aimed at preparing the corps of teachers whose educational level and personal and moral qualities, the system of values, behavioral algorithms correspond to the social portrait and the requirements of the state [4, p.36]. Using the example as the main educational method, the Chinese put forward demands for a teacher as the ultimate product of the education system (and not to a student, as is done in many countries around the world). It is the teacher who is a model of a pure man, because to him/her the state delegates the authority to educate the younger generation and the nation as whole.

Based on the concept that patriotism, citizenship, social competence are not innate human qualities, in particular the teachers`ones, the Chinese education system pays tight attention to the conscious and purposeful formation of these personal 
characteristics in their citizens, starting with kindergarten. In the system of vocational training of teachers in the country's higher educational institutions from 30 to $48 \%$ [3, p. 13] of the disciplines (depending on the specialization) are in one way or another related to the subjects of the civil cycle. Today China stands at the positions of conscious, gradual and planned formation of teachers' civic competence as the main task of the system of professional training of this category of specialists, using for this purpose certain mechanisms, forms of classroom, non-classroom and individual work with teachers-to-be during their studies at the pedagogical universities of the country

\section{References:}

1. Bernstein, J.L. (2008). Cultivating Civic Competence: Simulations and Skill-Building in an Introductory Government Class. Journal of Political Science Education,4(1), 1-20.

2. Kokom, K. (2009). The Effect of Contextual Learning in Civic Education on Students' Civic Competence. Journal of Social Sciences, 5(4): 261-270.

3. Wu, P. (2017). Professional and moral qualities of a teacher. Zhejiang Pedagogical College Review, 435 (10), 12-15. (in Chinese)

4. Zhang, C. (2016). Citizenship and patriotical education of choreography teachers-to-be. Chinese educational Journal, 18, 34-38. (in Chinese) 